\title{
MODEL PERAN ANTAR KELEMBAGAAN DESA DALAM PENYEDIAAN AIR BAKU MELALUI PARADIGMA KEPEDULIAN AIR (Studi Kasus Desa Bendungan, Kecamatan Ciawi, Kabupaten Bogor)
}

\author{
Agus Susanto1) \\ M. Yanuar J. Purwanto2) \\ Bambang Pramudya3) \\ Etty Riani4) \\ 1)Program Studi IImu Pengelolaan Sumberdaya Alam dan Lingkungan, IPB \\ 2)DepartemenTeknik Sipil dan Lingkungan,IPB \\ 3)DepartemenTeknologi Industri Pertanian,IPB \\ 4)Departemen Manajemen Sumberdaya Peairan, IPB \\ e-mail: sugus.susanto@gmail.com
}

\begin{abstract}
Based on water balance and temporal water sufficiency analysis in Ciliwung Hulu watershed, it shows that Ciseuseupan sub watershed belongs toinsufficient water category. Of the 8 villages in the Ciseuseupan sub watershed, there is a Bendungan village that is not enough water category in the provision of raw water, because in the provision of raw water is still dependent on natural reliability such as rivers, springs, wells, and others. This research discusses insufficient water solutions at the village level with one of them is institutional analysis through concern of water paradigm. The method used is ISM (Interpretative Structural Model), with emphasis on 4 (four) elements structured in relation to the provision of raw water ie: (1) needs of the program, (2) the main obstacle, (3) purpose program, and (4) institutions involved in program implementation. Therefore, it is required an independent water provision expert, involving various parties. The purpose of this research is to build an institutional role model in the provision of concern of water paradigm. The results show that: to realize a new paradigm in the provision of raw water, the main constraint is quality of human resources (village officials, communities, and NGOs), which must be resolved first, so that they can participate together to build the infrastructure by adequate socialization.
\end{abstract}

Keywords: human resources quality, infrastructure, socialization, raw water

\begin{abstract}
ABSTRAK
Berdasarkan analisis neraca air dan ketercukupan air temporal DAS Ciliwung Hulu menunjukkan bahwa Sub DAS Ciseuseupan termasuk ke dalam kategori kurang cukup air dalam penyediaan air baku. Dari delapan desa yang ada di Sub DAS tersebut, Desa Bendungan merupakan salah satu desa yang ketercukupan airnya termasuk dalam kategori tidak cukup, sebab dalam penyediaan airnya masih mengandalkan alam, seperti sungai, air tanah melalui sumur, mata air, dan lain-lain. Penelitian ini menjelaskan solusi ketidak cukupan di tingkat desa, dimana salah satunya adalah dengan analisis peran antar kelembagaan melalui paradigma kepedulian air. Metode yang digunakan adalah ISM (Interpretative Structural Model), yang menekankan pada empat elemen yang berhubungan
\end{abstract}


dengan penyediaan air baku, yaitu: (1) kebutuhan program, (2) kendala utama, (3) tujuan program, dan (4) lembaga yang terkait dengan program. Oleh karena itu, diperlukan ahli penyediaan air mandiri, yang melibatkan berbagai pihak. Tujuan dari penelitian ini adalah membangun struktur model kelembagaan penyediaan air baku melalui paradigma kepedulian air. Hasil analisis menunjukkan bahwa: untuk merealisasikan paradigma baru di dalam penyediaan air baku,kendala utamanya adalah kualitas sumber daya manusia (aparat desa, masyarakat, dan LSM) yang harus diatasi terlebih dahulu agar mereka dapat berpartisipasi bersama-sama untuk membangun infrastruktur air melalui sosialisasi yang memadai.

Kata kunci: sumberdaya manusia, infrastruktur, sosialisasi, air baku

Desa memiliki fungsi penting bagi masyarakat dalam perkembangan daerah di sekitarnya, namun selama ini desa selalu termarginalkan, kurang mandiri, karena konsep perdesaan terkesan masih dipandang dengan perspektif sempit.Hal ini disebabkan karenakualitas sumber daya manusia (SDM) yang masih rendah, sehingga kurang berperan dalam pembangunan. Namun dengan diundangkannya UU No. 6 tahun 2014 tentang Desa, maka desa diharapkan menjadi lebih mandiri.Terlebih setelah dicanangkan program kerja pemerintahan sekarang (2014-2019) yaitu melalui program Nawacita, yang dituangkan dalam Nawacita ke tujuh yakni "Pemerintah mewujudkan kemandirian ekonomi dengan menggerakkan sektor-sektor strategis ekonomi domestik dengan prioritas pembangunan yakni peningkatan kedaulatan pangan dan peningkatan ketahanan air". Kebijakan tersebut ditempuh karena masih rendahnya akses dan tingkat pelayanan air bersih dan sehat di perdesaan.

Dalam memenuhi kebutuhan akan air baku, masyarakat perdesaan masih mengandalkan kepada ketersediaan sumber alam, seperti air sungai, mata air, air tanah melalui sumur,baik sumur gali maupun sumur pompa, dan setu atau embung. Ketergantungan masyarakat terhadap alam tersebut menyebabkan posisi masyarakat perdesaan terhadap ketersediaan air baku relatif rawan, karena variasi kondisi alam dalam menghasilkan air akan sangat menentukan bagaimana kebutuhan air baku masyarakat perdesaan tersebut akan dapat dipenuhi (Purwakusuma, Baskoro, \& Sinukaban, 2011).

Fenomena kebutuhan air baku perdesaan yang dipenuhi dari alam dapat dijumpai pada desa-desa yang ada di wilayah DAS Ciliwung Hulu. Berdasarkan analisis ketercukupan air, didapatkan bahwa sub DAS Ciseuseupan yang tersusun atas delapan desa termasuk ke dalam katagori sub DAS kurang cukup air dengan bobot (skor) 3. Dari delapan desa tersebut, Desa Bendungan merupakan desa yang ketercukupan air temporalnyatermasuk ke dalam kategori tidak cukup air (skor 4), dalam penyediaan air baku. Selain itu, angka kepadatan penduduknyatertinggi dibandingkan dengan desa-desalainnya, yaitu mencapai $7.615 \mathrm{jiwa} / \mathrm{km}^{2}$. Penyediaan air baku bagi masyarakat kurang mampu masih konvensional, yaitu dengan menampung mata air di tebing-tebing sungai yang ditampung dalam bak penampung dan apabila musim kemarau akan kering.Akses untuk mencapai sumber air cukup jauh, dan sanitasi lingkungan yang buruk menambah permasalahan air baku di desa.

Untuk mengatasi permasalahan dalam memenuhi penyediaan air baku di tingkat desa diperlukan paradigma baru yaitukepedulian air. Paradigma tersebut menjelaskan bahwa desa merupakan tampungan air yang meliputi air hujan, sisa air buangan, dan air limbah baik domestik maupun non domestik. Air tersebut ditahan selama mungkin, kemudian dimanfaatkan kembali 
sebagai air baku melalui instalasi pengolah air limbah.Untuk mendukung paradigma tersebut, maka dilakukan penelitian pengembangan struktur hubungan peran antar kelembagaan dalam penyediaan air baku. Menurut Dunn (2003) keberhasilan suatu kegiatan/usaha salah satunya ditentukan oleh mekanisme peran identitas elemen yang ada kaitannya antar kelembagaan pada program tersebut, sehingga tujuannya dapat tercapai.

Tujuan dari penelitian ini adalah untuk membangun struktur model elemen penting dan mekanisme peran antar kelembagaan desa dalam penyediaan air baku melalui paradigma kepedulian air di Desa Bendungan, Kecamatan Ciawi, Kabupaten Bogor.

\section{METODE}

Lokasi penelitian terletak di desa Bendungan. Secara administratif terletak di Kecamatan Ciawi, Kabupaten Bogor yang berada pada koordinat 606'55"-606'76" LS, dan 10608'25"-10608;59" BT. Pemilihan lokasi berdasarkan hasil analisis ketersediaan air dan ketercukupan air. Hasil analisis ketercukupan air temporal (IKaT) menunjukkan bahwa Desa Bendungan termasuk ke dalam kategori desa yang tidak cukup air dengan skor 4. Secara hidrologis Desa Bendungan berada pada Sub DAS Ciseuseupan, dimana berdasarkan analisis ketercukupan airnya termasuk ke dalam katagori kurang cukup. Lokasi penelitian disajikan dalam Gambar 1.

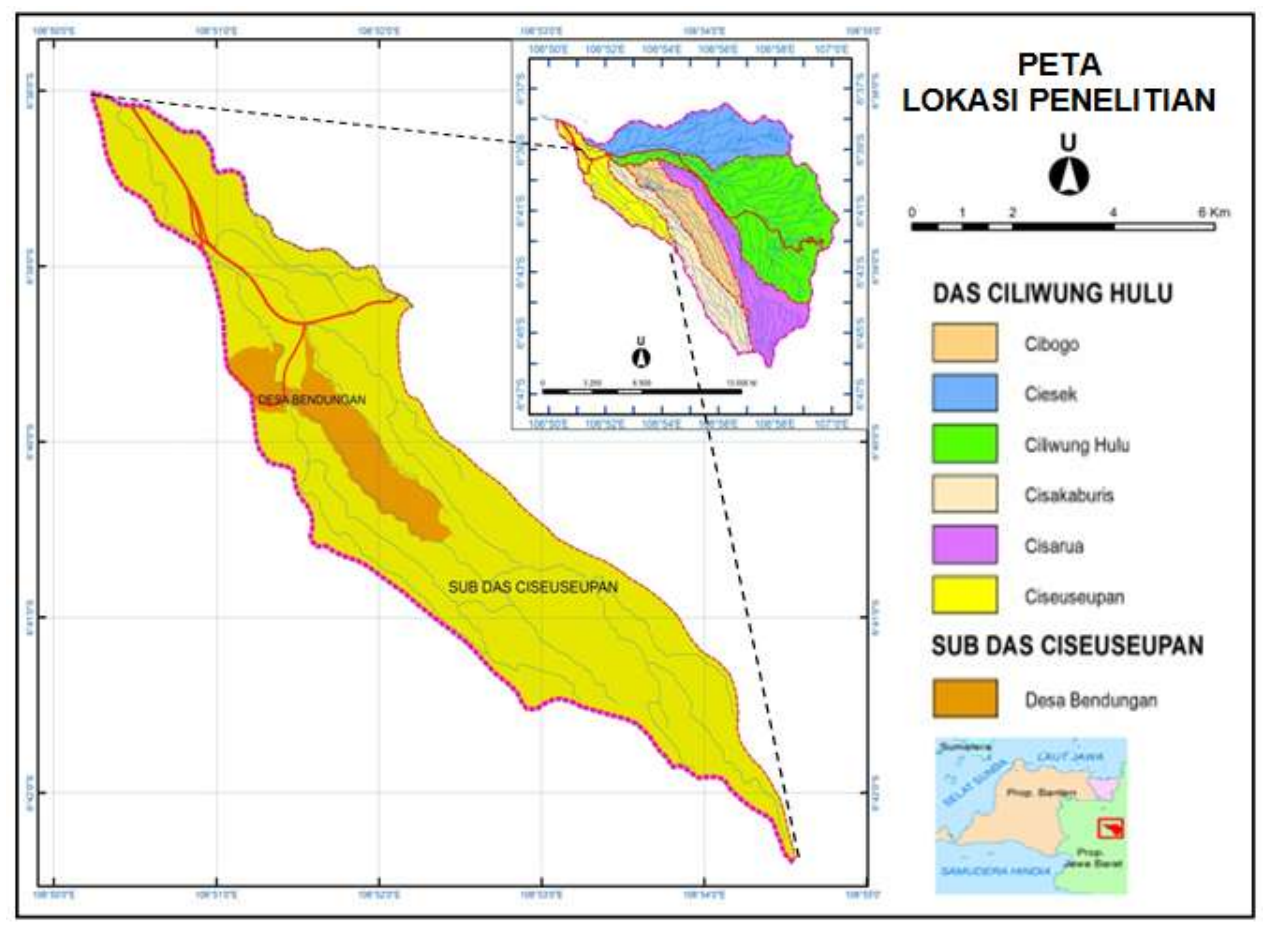

Gambar 1. Lokasi Penelitian Desa Bendungan, Kecamatan Ciawi, Sub DAS Ciseuseupan

Pengolahan data penelitian ini menggunakan master soft ware ISM (Interpretative Structural Modelling). Data yang digunakan adalah data sekunder dan primer. Data sekunder diperoleh dari Badan Statistik Kabupaten Bogor tahun 2010-2015, monografi Desa Bendungan tahun 2015, 
Rencana Tata Ruang Wilayah (RTRW) Kabupaten Bogor tahun 2008-2028, dan literatur yang berkaitan dengan pengembangan kelembagaan. Sedangkan data primer diperoleh berdasarkan wawancara mendalam dengan pakar yang berjumlah lima responden, yaitu: 1) Dinas PU Propinsi Jawa Barat, 2) Bappeda Kabupaten Bogor, 3) Staf Camat Ciawi, dan 4) tokoh masyarakat Desa Bendungan, dan (5) pakar yang dipilih untuk verifikasi data, serta observasi lapangan. Metode yang digunakan adalah wawancara langsung dengan menggunakan instrumen ISM. Adapun langkahlangkah yang dilakukan, yaitu dengan: (1) identifikasi elemen, (2) hubungan kontekstual elemen, (3) SSIM (Structural Self Interaction Matrix), (4) RM (Reachability Matrix), (5) Digraph, dan (6) ISM (pembahasan hasil analisis).

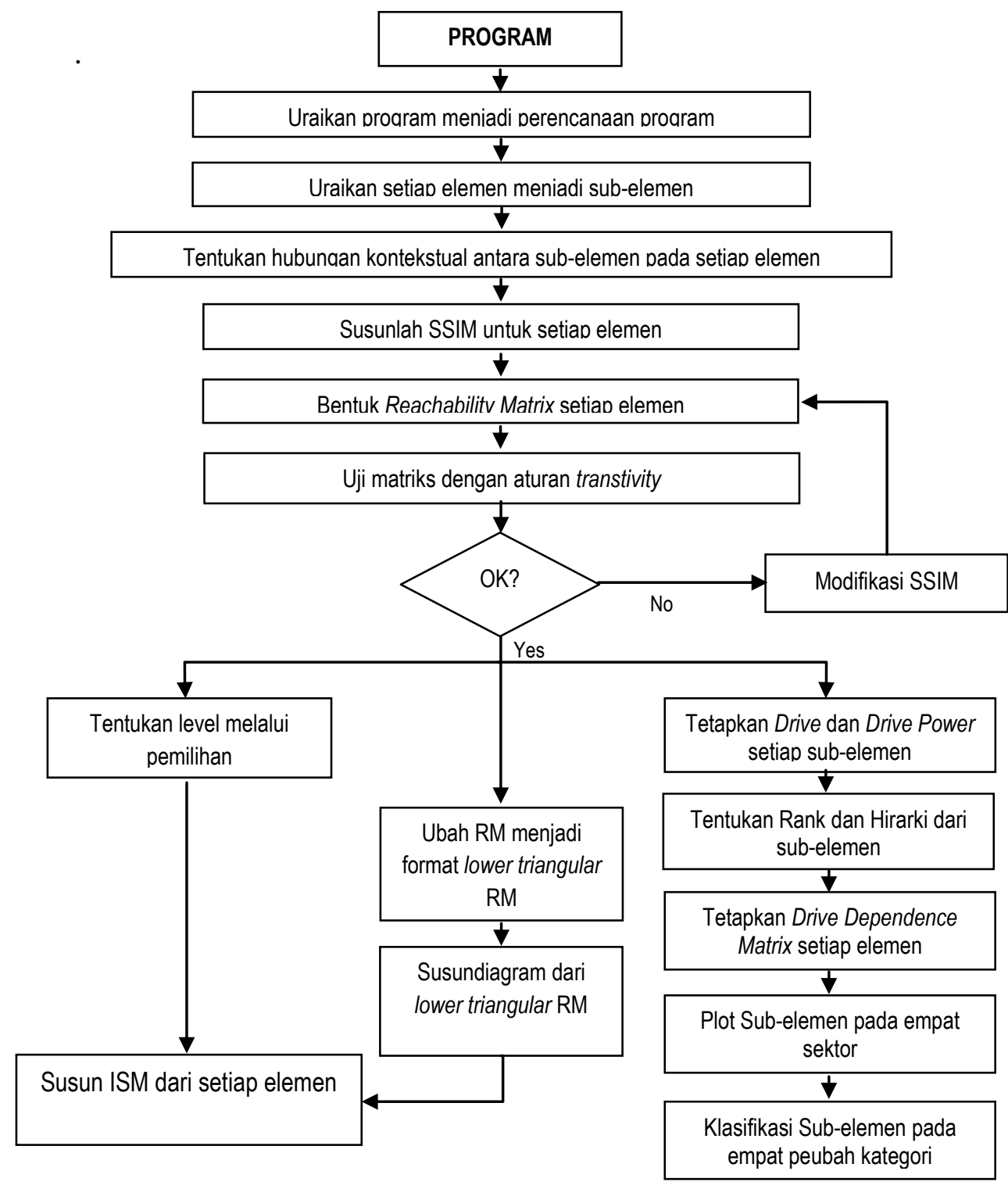

Sumber: Saxena dalam Marimin (2004)

Gambar 2. Tahapan analisis dalam software ISM 
Analisis data dilakukan menggunakan metode ISM dengan input: kebutuhan program, kendala utama, tujuan program, dan lembaga yang terlibat dalam pelaksanaan program penyediaan air baku tingkat desa, yaitu Desa Bendungan, Kecamatan Ciawi, Kabupaten Bogor (Eriyanto \& Sofyar, 2007). Langkah-langkah penyusunan ISM disajikan dalam Gambar 2.

Identifikasi elemen adalah tahap awal untuk menganalisis elemen-elemen yang terkait berdasarkan teori dan pendapat pakar (expert judgment). Metode yang digunakan adalah wawancara, dan dengan melihat tugas pokok dan fungsi (tupoksi) masing-masing elemen.

Hubungan kontekstual adalah keterkaitan antar sub-elemen yang dinyatakandalam baris dan kolom. Keterkaitan antar sub-elemen tersebut dijelaskan dengan pembandingan antar sub-elemen, yaitu sub-elemen $A$ lebih penting dari pada sub-elemen $B$, begitu juga sebaliknya.

Berdasarkan hubungan-hubungan kontekstual, maka disusun Structural Self Interaction Matrix (SSIM), yang menggunakan simbol V, A, X, dan O, dimana:

$\checkmark$ jika e $\mathrm{e}_{\mathrm{j}}=1$ dan $\mathrm{e}_{\mathrm{j}} \mathrm{i}=0$

$A$ jika $e_{j}=0$ dan $e_{j} i=1$

$X j i k a$ eij $=0$ dan $e_{j} i=0$

0 jika eij $=0$ dan $e_{j} i=1$

- $\quad$ Nilai ei $\mathrm{i}_{\mathrm{j}}=1$; ada hubungan kontekstual antara sub-elemen ke-i dan ke-j; nilai eji = 0; tidak ada hubungan kontekstual antara sub-elemen ke-i dan ke-j.

- $\quad V j i k a ~ e i_{j}=1$ dan eji = 0; V = sub-elemen ke-i harus lebih dulu ditangani dibandingkan subelemen ke-j.

- $\quad A$ jika eij $=0$ dan $e_{j} \mathrm{i}=1 ; \mathrm{A}=$ sub-elemen ke-j harus lebih dulu ditangani dibandingkan dengan sub-elemen ke-i.

- $\quad X$ jika e $i_{j}=1$ dan $e_{j} \mathrm{i}=1 ; X=$ kedua sub-elemen harus ditangani bersama-sama.

- $\quad$ O jika eij $=0$ dan ej $=0 ; 0=$ kedua sub-elemen bukan prioritas yang ditangani.

Langkah selanjutnya adalah membandingkan baris ke dalam kolom untuk hubungan antar faktor kunci dalam bentuk huruf $(\mathrm{V}, \mathrm{A}, \mathrm{X}, \mathrm{O})$, seperti disajikan dalam Tabel 1.

Tabel 1. Matriks SSIM

\begin{tabular}{|c|c|c|c|c|c|c|c|c|}
\hline \multirow{2}{*}{ Sub-elemen Tujuan ke-i } & \multicolumn{8}{|c|}{ Sub-elemen Tujuan ke-j } \\
\hline & 1 & 2 & 3 & 4 & 5 & 6 & 7 & 8 \\
\hline 1 & $\mathrm{X}$ & V & V & A & $A$ & 0 & 0 & $X$ \\
\hline 2 & & $X$ & 0 & 0 & $X$ & V & V & V \\
\hline 3 & & & $X$ & $A$ & $A$ & $x$ & $X$ & V \\
\hline 4 & & & & $x$ & $\mathrm{~V}$ & 0 & 0 & 0 \\
\hline 5 & & & & & $x$ & V & V & V \\
\hline 6 & & & & & & $x$ & A & $A$ \\
\hline 7 & & & & & & & $x$ & $x$ \\
\hline 8 & & & & & & & & $X$ \\
\hline
\end{tabular}

Reachability matrix (RM) adalah hubungan antaraelemen i dan j yang dinyatakan dengan angka 1 dan 0 . Simbol 1 menyatakanterdapat atau ada hubungan kontekstual, sedangkan simbol 0 menyatakan tidak terdapat hubungan kontekstual antara elemen i dan j, demikian sebaliknya. Setelah SSIM terisi sesuai pendapat responden, maka simbol ( $V, A, X, O)$ dapat digantikan dengan simbol (1 dan 0) dengan ketentuan yang ada sehingga dapat diketahui nilai dari hasil RM (Gambar 3) 


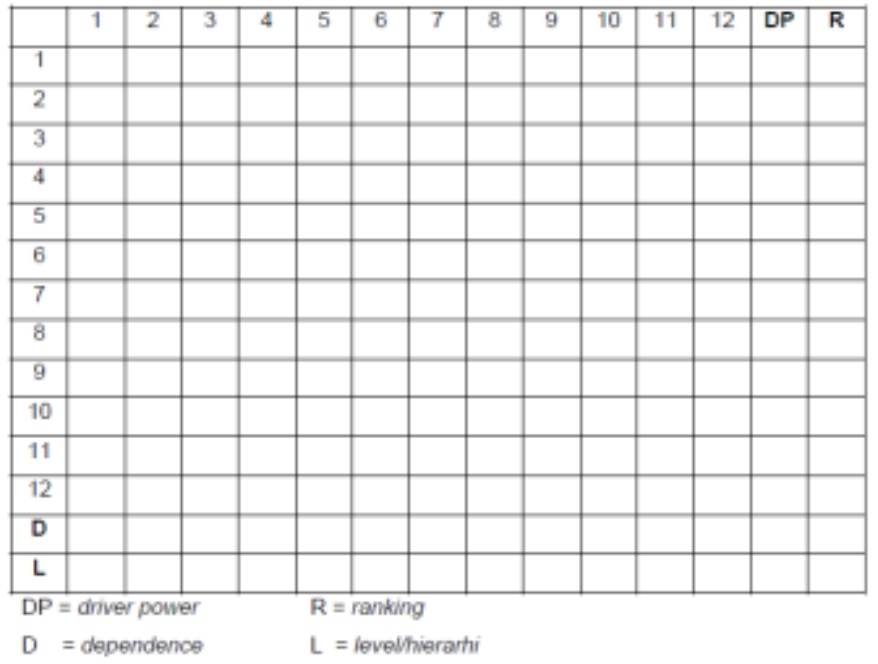

Gambar 3. Reachability Matrix (RM)

Digraph (directional graph) adalah tahap dimana hasil Reachability Matrix diplotkan ke dalam grafik, sehingga dapat melihat hubungan antar sub-elemen dalam diagram hirarki (berjenjang) atau dalam matriks Driver Power (DP) dengan ketentuan sebagai berikut.

- $\quad$ Sektor 1; weak driver-weak dependent variables (Autonomous); Sub-elemen yang masuk pada sektor 1 jika: nilai $\mathrm{DP} \leq 0,5 \mathrm{X}$ dan nilai $\mathrm{D} \leq 0,5 \mathrm{X}, \mathrm{X}$ adalah jumlah elemen

- $\quad$ Sektor 2; weak driver-strongly dependent variables (Dependent); Sub-elemen yang masuk pada sektor 2 jika: Nilai DP $\leq 0,5 \mathrm{X}$ dan nilai $\mathrm{D} \geq 0,5 \mathrm{X}$

- $\quad$ Sektor 3; strong driver - strongly deopendent variables (Linkage); Sub-elemen yang masuk pada sektor 3 jika: Nilai DP > 0,5X dan nilai $\mathrm{D}>0,5 \mathrm{X}$

- $\quad$ Sektor 4; strong driver-weak dependent variables (Independent); Sub-elemen yang masuk pada sektor 4 jika: Nilai DP > 0,5 X dan nilai D $\leq 0,5$ X.Secara rinci Digraph disajikan dalam Gambar 4.

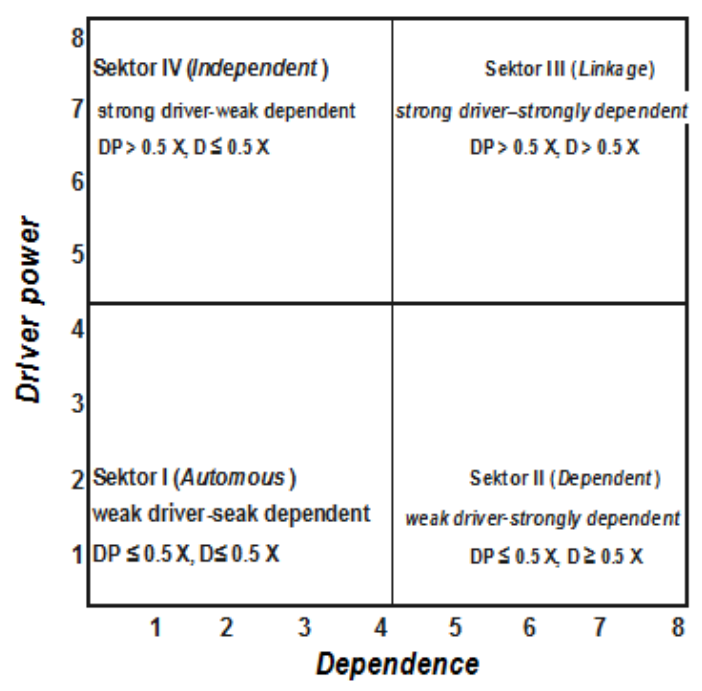

Gambar 4. Diagram Digraph dalam ISM 


\section{HASIL DAN PEMBAHASAN}

Untuk mendukung peran desa dalam penyediaan air baku dengan paradigma baru kepedulian air, maka diperlukan struktur peran antar kelembagaan yaitu menstrukturkan kelembagaan yang ada dalam penyediaan air baku agar mempermudah dalam implementasi.

Berdasarkan hasil analisis ketercukupan air temporal menunjukkan bahwa Desa Bendungan dalam penyediaan air baku tidak cukup air, sehingga diperlukan solusi penanganannya. Salah satu solusi adalah dengan analissis kelembagaan. Analisis kelembagaan adalah menstrukturkan fungsi dan peran antar lembaga-lembaga yang terkait. Harapannya adalah agar penyediaan air baku di Desa Bendungan dapat tercukupi secara berkelanjutan.

Berdasarkan hasil identifikasi elemen kelembagaan dari beberapa sumber diantaranya yaitu: Sianipar (2012), Nuraini, Dwidjono,Masyuri, \& J amhari, (2016), Mirah (2014), Susanto (2010), Thamrin (2009), dan Marpaung (2011), serta melalui wawancara secara mendalam dengan pakar, maka ditetapkan empat elemen dalam pengembangan struktur peran antar kelembagaan penyediaan air baku yaitu: (1) kebutuhan program, (2) kendala utama, (3) tujuan program, dan (4) elemen lembaga terlibat dalam pelaksanaan program. Setiap elemen yang dikaji dijabarkan menjadi sejumlah sub-elemen berdasarkan masukan dari pakar, kemudian ditetapkan hubungan kontekstual antar sub-elemen. Hubungan antar elemen dalam model pengembangan peran antar kelembagaan disajikan dalam Gambar 5.

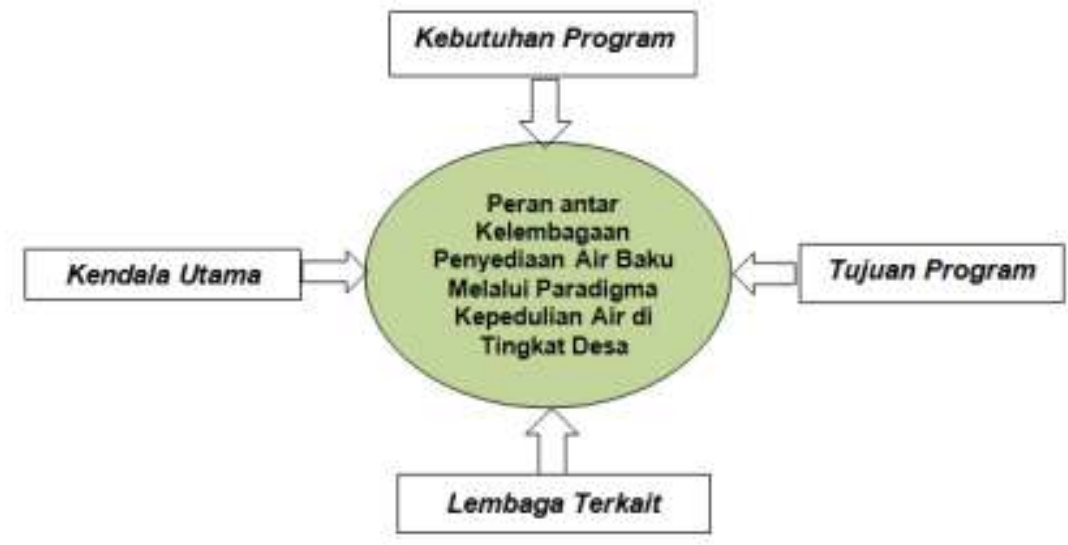

Gambar 5. Hubungan antar elemen dalam peran antar kelembagaan pada penyediaan air baku melalui paradigma kepedulian air di Desa Bendungan

\section{Kebutuhan Program dalam Penyediaan Air Baku dengan Paradigma Kepedulian Air}

Berdasarkan hasil analisis atas pendapat pakar, ditemukan sembilansub-elemen kebutuhan program yang diperlukan dalam peningkatan peran desa dalam penyediaan air baku, yaitu: (A) ketersediaan infrastruktur, (B) kualitas SDM, (C) kerjasama lintas sektor, (D) tenaga teknis lapangan, (E) kemudahan birokrasi (insentif dan disinsentif), (F) sistem pengelolaan air bersih, (G) sosialisasi, (H) partisipasi masyarakat, dan (I) kelembagaan pengelolaan air bersih. Hasil analisis kebutuhan program dengan ISM, menunjukkan bahwa: sebaran setiap sub-elemen kebutuhan program di dalam Digraph menempati tiga sector, yaitu sektor II, III, dan IV, seperti terlihat pada Gambar 6A. Dapat dijelaskan bahwa: sub-elemen kekuatan penggerak (driver power) masih terbatasnya infrastruktur 
penyediaan air baku (A), kerjasama lintas sektoral (C), dan sosialisasi $(G)$ terletak pada sektor IV yang merupakan sub-sektor elemen kunci yang sangat berpengaruh dalam penyediaan air baku. Sub-elemen tersebut mempunyai pengaruhyang besar dalam penyediaan air baku di tingkat sub DAS dengan tingkat ketergantungan (dependence) yang rendah terhadap sub-elemen kebutuhan lainnya.

Apabila ketiga sub-elemen tersebut tidak ditangani dengan baik, maka akan menjadi faktor penghambat utama terhadap program penyediaan air bersih di tingkat desa. Kenyataan menunjukkan bahwa pada beberapa desa lain yang ada di Sub DAS Ciseuseupan belum mempunyai penyediaan air baku, kalaupun ada, masih berupa bak tampung sederhana yang diusahakan oleh masyarakat desa itu sendiri, selain itu, jarang sekali dilakukan sosialisasi tentang penyediaan air.

Kerjasama lintas sektoral yang masih lemah merupakan faktor penghambat dalam kebutuhan program penyediaan air baku di tingkat desa, sehingga yang terjadi adalah tidak ada atau jarang sekali dilakukan sosialisasi terhadap penyediaan air baku mandiri oleh masyarakat desa. Hal ini terjadi karena ketiadaan tenaga penyuluh lapangan. Apabila dikaitkan dengan sub-elemen kebutuhan program peningkatan peran desa dalam penyediaan air baku, maka penyediaan infrastruktur yang layak, kerjasama lintas sektor, dan kegiatan sosialisasi yang rutin sangat diperlukan.

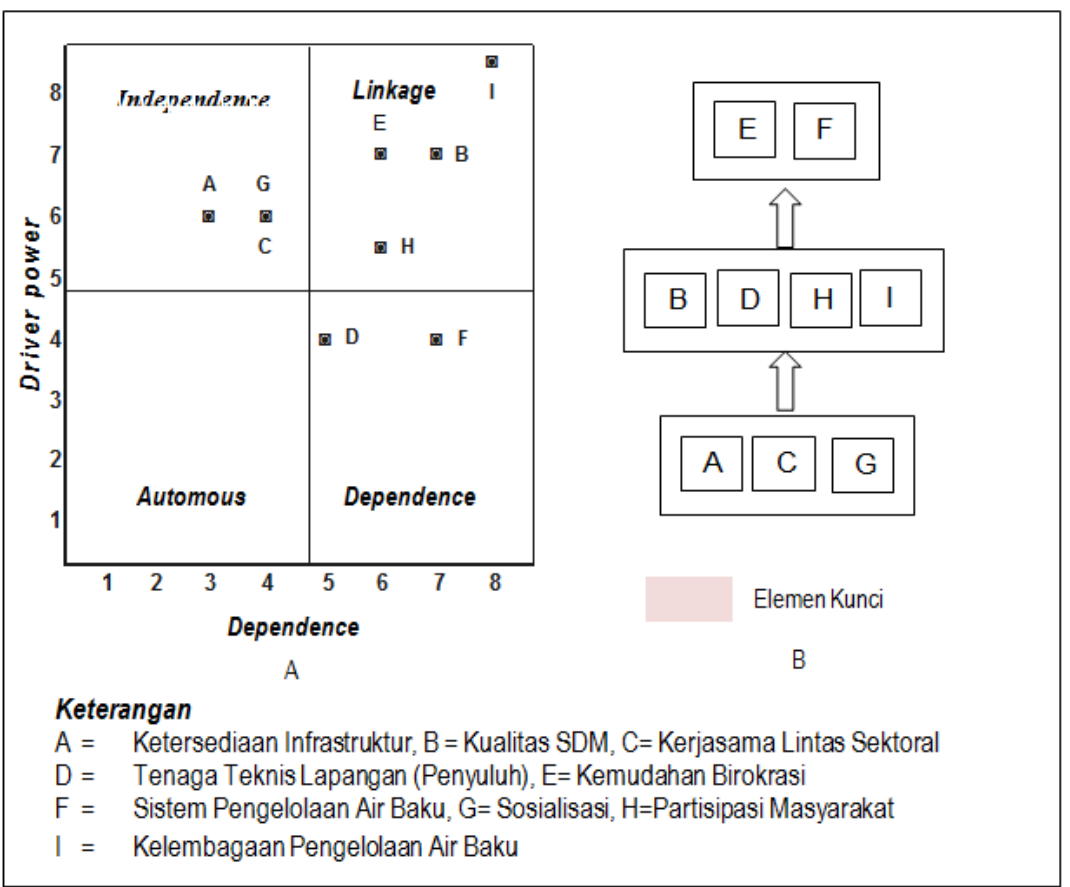

Gambar 6. Matrik Driver Power-Dependence dan struktur hirarki untuk elemen kebutuhan program dalam dalam penyediaan air baku di Desa Bendungan

Sub-elemen lain yang menjadi kebutuhan dalam rangka peningkatan peran desa dalam penyediaan air baku adalah: kualitas sumberdaya manusia $(B)$, keberadaan tenaga teknis lapangan yang handal $(\mathrm{D})$, dukungan partisipasi masyarakat $(\mathrm{H})$, dan terbentuknya kelembagaan pengelolaan yang baik (I). Sub-elemen ini terletak pada sektor III (linkage) yang merupakan sub-elemen yang 
mempunyai kekuatan pendorong terhadap keberhasilan program, namun memiliki ketergantungan (dependence) dengan sub-elemen kebutuhan lainnya sangat tinggi. Setiap tindakan terhadap kebutuhan pada sub-elemen ini akan mempengaruhi suksesnya program penyediaan air baku di tingkat desa dan sebaliknya apabila sub-elemen ini mendapatkan perhatian yang kurang, maka dapat mempengaruhi terhadap kegagalan program penyediaan air baku.

Sub-elemen kemudahan birokrasi (diberlakukannya insentif dan disinsentif) (E), serta adanya sistem pengelolaan air baku terletak di sektor II (dependence) yang merupakan sub-elemen akibat dari tindakan perbaikan kebutuhan program lainnya. Dengan kata lain apabila dua sub-elemen tersebut terpenuhi seperti sistem pengelolaan penyediaan air bersih yang berjalan dengan baik, ditambah dengan adanya insentif pada masyarakat yang menjaga lingkungan, demikian sebaliknya apabila masyarakat melanggar aturan yang telah disepakati bersama, maka akan mendapat penalti atau disinsentif, sehingga sub-elemen ini menjadi sangat penting.

Struktur hirarki hubungan antara sub-elemen kebutuhan program pengembangan penyediaan air bersih di tingkat desa, yaitu Desa Bendungan, Kecamatan Ciawi, Kabupaten Bogor disajikan dalam Gambar 6B. Dari Gambar 6B terlihat bahwa penanganan kebutuhan yang dihadapi dalam peningkatan peran desa dalam penyediaan air baku di Desa Bendungan, dapat dilakukan melalui tiga tahap (level). Pada tahap pertama yang perlu dilakukan adalah melengkapi atau menyediakan infrastruktur yang diperlukan, mengintensifkan kerjasama lintas sektoral seperti melibatkan swasta, LSM, dan perguruan tinggi serta mensosialisasikan secara rutin kepada masyarakat tentang penyediaan air baku. Apabila ketiga elemen tersebut dapatterpenuhi, didukung oleh sumberdaya manusia yang baik, dan dibantu dengan tenaga lapangan yang mumpuni, serta keterlibatan masyarakat, maka akan terbentuk kelembagaan yang akan mendorong kemudahan birokrasi yang akhirnya akan terbentuk pula sistem pengelolaan air baku yang baik di tingkat desa.

\section{Kendala Utama dalam Penyediaan Air Baku dengan Paradigma Kepedulian Air di Desa Bendungan}

Ditemukan sembilan sub-elemen kendala utama dalam penyediaan air baku di tingkat desa, yaitu: (A) masih terbatasnya infrastruktur, $(B)$ masih rendahnya kualitas sumberdaya manusia, (C) belum terbinanya kemitraan yang menguntungkan semua pihak, (D) tanggung jawab pemerintah daerah (Pemda) masih kecil, (E) tanggung jawab pemerintah pusat masih kecil dan hampir tidak ada, $(F)$ kerjasama lintas sektoral masih lemah, $(G)$ partisipasi masyarakat masih rendah, $(H)$ belum ada keterlibatan swasta, dan (I) belum terbentuk kelembagaan yang mengatur penyediaan air baku. Hasil analisis dengan menggunakan metode ISM kemudian diplot kedalam Digraph, menunjukkan bahwa sebaran setiap sub-elemen kendala menempati empat sektor yaitu sektor I, II, III dan IV, seperti terlihat pada Gambar 7A.

Masih terbatasnya infrastruktur (A), kualitas SDM (B), dan partisipasi masyarakat (G) menempati sektor IV yang merupakan elemen kunci, dan faktor penggerak. Kualitas sumberdaya manusia di desa tergolong masih rendah. Rendahnya sumberdaya manusia ini merupakan faktor penghambat, karena penduduk di Desa Bendungan umumnya (60-80\%) hanya mampu menikmati pendidikan dasar sampai pendidikan menengah pertama, dan bahkan banyak yang tidak tamat sekolah (BPS, 2015). Demikian pula dengan pendidikan nonformal, seperti pelatihan yang berkaitan dengan penyediaan air baku jarang atau bahkan belum pernah mereka peroleh. Selain itu, kegiatan sosialisasi yang berupa penyuluhan atau kegiatan lainnya yang berhubungan dengan penyediaan air baku jarang ada, dikarenakan tidak ada tenaga penyuluh, sehingga apabila dikaitkan dengan elemen 
kendala program penyediaan air baku di tingkat desa, maka penyediaan infrastruktur, peningkatan kualitas SDM, dan sosialisasi kegiatan merupakan kendala utama yang harus segera diselesaikan.

Sub-elemen lain yang merupakan kendala dalam penyediaan air baku di tingkat desa adalah belum terbentuknya kelembagaan yang mengatur penyediaan air baku(I). Sub-elemen ini terletak pada sektor III (linkage) yang merupakan sub-elemen yang mempunyai kekuatan pendorong terhadap keberhasilan program penyediaan air baku di tingkat desa, namun memiliki ketergantungan (dependence) dengan sub-elemen kendala lainnya sangat tinggi. Setiap tindakan terhadap kendala pada sub-elemen ini akan mempengaruhi suksesnya program penyediaan air baku di tingkat desa, dan sebaliknya apabila sub-elemen ini mendapatkan perhatian yang kurang, maka dapat mempengaruhi terhadap kegagalan program penyediaan air bersih di tingkat desa.

Sedangkan sub-elemen kemitraan $(\mathrm{C})$, tanggung jawab pemerintah daerah yang masih rendah (D), tanggung jawab pemerintah pusat yang masih kecil (E), dan kerjasama lintas sektoral masih lemah $(F)$, terletak di sektor II (dependence) yang merupakan sub-elemen akibat dari tindakan perbaikan kendala program lainnya. Dengan kata lain apabila beberapa sub-elemen kendala program ini terpenuhi seperti terjadi sinergitas antara pemerintah pusat dengan pemerintah daerah dan menjalin kerjasama dengan institusi lain, maka sub-elemen ini menjadi sangat penting.

Sub-elemen terakhir yang menjadi kendala dalam pengembangan penyediaan air baku di tingkat desa adalah keterlibatan swasta yang masih kecil $(\mathrm{H})$. Sub-elemen ini terletak pada sektor I (autonomous). Sub-elemen ini mempunyai keterkaitan dengan peningkatan peran desa dalam penyediaan air baku sangat kecil dan bahkan belum ada.

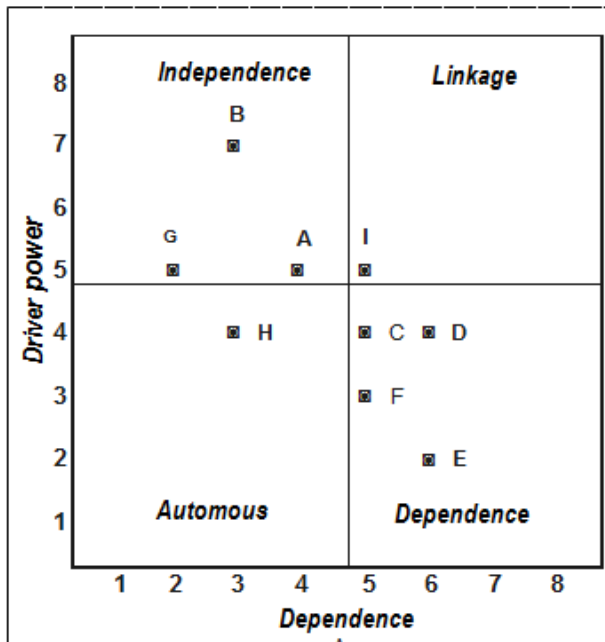

A

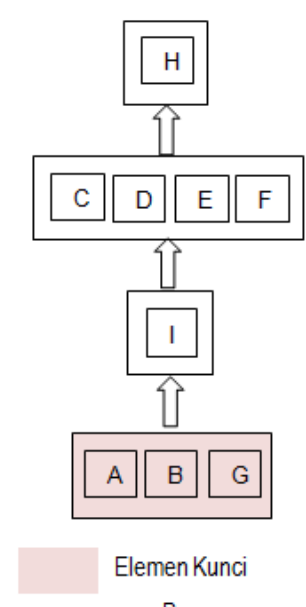

B

Keterangan

$A=$ Ketersediaan Infrastruktur, $B=$ Kualitas $S D M, C=$ Kemitraan,

$\mathrm{D}=$ Tanggung Jawab Pemerintah Daerah, $\mathrm{E}=$ Tanggung Jawab Pemerintah Pusat,

$\mathrm{F}=$ Kerjasama Lintas Sektoral, $\mathrm{G}=$ Partisipasi Masyarakat, $\mathrm{H}=$ Keterlibatan Swasta

I =Kelembagaan Pengelolaan Penyediaan Air Baku

Sumber: Hasil analisis, 2016

Gambar 7. Matrik Driver Power-Dependence dan struktur hirarkielemen kendala dalam peran desa dalam penyediaan air baku di Desa Bendungan 
Peran masyarakat untuk penyediaan air baku adalah dengan swadaya, yaitu dengan membuat bakbak kecil penampungan air di sekitar rumah. Keterlibatan pihak swasta bisa penting apabila dapat memberi atau berkontribusi dalam bentuk ikut mensosialisasikan pentingnya penyediaan air baku, terlebih lagi apabila berkontribusi terhadap infrastruktur. Struktur hirarki hubungan antara sub-elemen kendala program peningkatan peran desa dalam penyediaan air baku di tingkat desa, yaitu Desa Bendungan, Kecamatan Ciawi, Kabupaten Bogor disajikan dalam Gambar 7B, dan terlihat bahwa penanganan kendala yang dihadapi dalam pengembangan penyediaan air baku dapat dilakukan melalui empat tahap.

Pada tahap pertama yang perlu dilakukan adalah melengkapi atau menyediakan infrastruktur yang diperlukan. Selain itu, peningkatan kualitas sumberdaya manusia melalui pembekalan dengan berbagai keterampilan dan penguasaan teknologi, dan yang tidak kalah penting adalah melibatkan masyarakat. Pelibatan masyarakat dimulai dari proses perencanaan, pelaksanaan, dan bahkan sampai pada tahap pengawasan. Masyarakat merupakan unsur utama atau unsur penggerak yang nantinya harus berprakarsa secara mandiri. Selama ini keterlibatan pemerintah baik pemerintah daerah maupun pusat terhadap penyediaan air baku masih rendah, lebih-lebih keterlibatan pihak swasta hampir tidak ada. Untuk itu, diperlukan kelembagaan yang kuat. Menurut Dunn (2003) suatu kegiatan diperlukan kelembagaan yang kuat baik struktur maupun peraturan perundangannya.

\section{Tujuan Program dalam Penyediaan Air Baku dengan Paradigma Kepedulian Air di Desa Bendungan}

Hasil pendapat pakar dan observasi lapangan, ditemukan sembilan sub-elemen tujuan program yang diperlukan dalam peningkatan peran desa dalam penyediaan air bakuyaitu: $(A)$ ketersediaan infrastruktur, (B) kesadaran masyarakat, (C) Sistem Operasional Prosedur (SOP), (D) kontinuitas pasokan air, (E) partisipasi masyarakat, (F) sistem pengelolaan sumber air untuk air baku, (G) ketercukupan air baku masyarakat perdesaan, $(\mathrm{H})$ keterlibatan aparat desa, dan (I) kelembagaan pengelolaan air bersih.

Hasil analisis memperlihatkan bahwa: sebaran setiap sub-elemen tujuan program menempati empat sektor, seperti terlihat pada Gambar 8A. Dari Gambar 8A dapat dijelaskan bahwa sub-elemen masih terbatasnya infrastruktur penyediaan air baku $(A)$, partisipasi masyarakat $(E)$, dan keterlibatan aparat desa $(\mathrm{H})$ terletak pada sektor IV yang merupakan sub sektor elemen kunci yang sangat berpengaruh dalam penyediaan air baku di Desa Bendungan. Sub-elemen tersebut merupakan kekuatan penggerak (driver power) yang besar dengan tingkat ketergantungan (dependence) yang rendah terhadap sub-elemen tujuan program lainnya.

Keterlibatan aparatur desa dalam menangani penyediaan air baku merupakan faktor penghambat dalam tujuan program, sehingga yang terjadi adalah tidak terkoordinirnya penyediaan air baku, akibatnya adalah masyarakat secara komunal membangun bak-bak penampungan dari mata air di tebing-tebing sungai, namun apabila terjadi kemarau panjang mengalami kekeringan. Apabila dikaitkan dengan sub-elemen tujuan program peningkatan peran desa dalam penyediaan air baku di tingkat desa, maka penyediaan infrastruktur yang layak, partisipasi masyarakat yang masih rendah, dan keterlibatan aparatur desa dalam penyediaan air baku sangat diperlukan.

Sub-elemen lain yang menjadi tujuan program meliputi: Sistem Operasional Prosedur (SOP) (C), sistem pengelolaan sumber air untuk air baku (F), dan kelembagaan pengelolaan air baku (I), terletak di sektor III (linkage). Sub-elemen ini mempunyai kekuatan pendorong terhadap keberhasilan program, namun memiliki ketergantungan (dependence) dengan sub-elemen tujuan program lainnya yang sangat tinggi. Setiap tindakan terhadap tujuan program pada sub-elemen ini akan 
mempengaruhi suksesnya program peningkatan peran desa dalam penyediaan air baku, dan sebaliknya apabila sub-elemen ini mendapatkan perhatian yang kurang, maka dapat mempengaruhi kegagalan program peningkatan peran desa dalam penyediaan air baku.

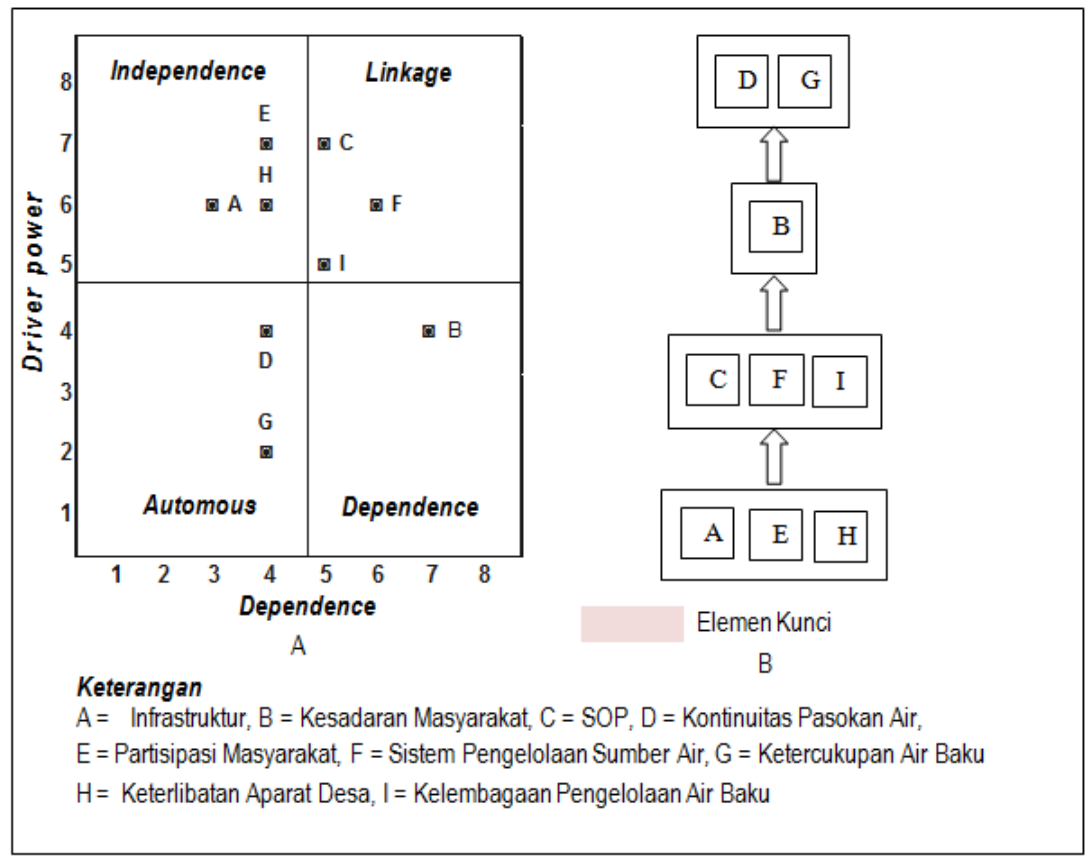

Sumber: Hasil analisis, 2016

Gambar 8. Matrik Driver Power-Dependencedan struktur hirarkielemen tujuan program peningkatan peran desa dalam penyediaan air baku di Desa Bendungan

Keempat kendala tersebut, apabila dikaitkan dengan elemen tujuan program peningkatan peran desa dalam penyediaan air bakumerupakan kendala utama, sehingga sebaiknya segera diuraikan atau diselesaikan dalam rangka penyediaan air baku.Sedangkan sub-elemen kesadaran masyarakat (B) terletak di sektor II (dependence) merupakan sub-elemen akibat dari tindakan perbaikan tujuan program lainnya. Apabila beberapa sub-elemen tujuan program peningkatan peran desa dalam penyediaan air baku di tingkat desa ini sudah terpenuhi, maka sub-elemen ini menjadi sangat penting.

Sub-elemen terakhir yang menjadi tujuan program dalam peningkatan peran desa pada penyediaan air baku adalah kontinuitas pasokan air (D), dan ketercukupan air baku masyarakat perdesaan (G). Kedua sub-elemen ini terletak pada sektor I (autonomous), yaitu sub-elemenyang mempunyai keterkaitan dengan peningkatan peran desa dalam penyediaan air baku sangat kecil dan bahkan belum ada. Akibatnya adalah masyarakat dalam memenuhi kebutuhan akan air baku membuat bak-bak kecil penampungan air secara swadaya. Apabila dikaitkan dengan sub-elemen lainnya dalam tujuan program dapat diselesaikan, maka secara otomatis ketercukupan air baku di Desa Bendungan akan berjalan dengan baik.

Struktur hirarki hubungan antar sub-elementujuan program peningkatan peran desa dalam penyediaan air baku di Desa Bendungan disajikan dalam Gambar 8B, dan terlihat bahwa 
penanganan tujuan program yang dihadapi dapat dilakukan melalui empat tahap. Pada tahap pertama yang perlu dilakukan adalah melengkapi atau menyediakan infrastruktur yang diperlukan dalam penyediaan air. Program ini tidak akan berhasil kalau tidak ada peran aktif dari aparatur desa dan partisipasi dari masyarakat. Pada saat ini, keterlibatan aparatur desa sangat kecil. Keterlibatan aparat desa baru kelihatan apabila ada bantuan dari Pemerintah baik dari Pusat atau Kabupaten.

Pada level ke dua keterlibatan aparatur desa lebih diintensifkan. Hal ini akan mendorong partisipasi masyarakat yang tinggi terhadap penyediaan air baku. Level ini tidak berjalan apabila tidak didukung oleh sistem pengelolaan sumber air yang baik, karena apabila pengelolaan sumber air berjalan dengan baik, maka akan berpengaruh terhadap pasokan (kontinuitas) sumber air baku. Tujuan akhir dari penyediaan air baku adalah ketercukupan air baku bagi masyarakat baik dari segi kuantitas maupun kualitasnya.

\section{Lembaga yang Terlibat dalam Pelaksanaan Program Peran Antar Kelembagaan pada Penyediaan Air Baku dengan Paradigma Kepedulian Air di Desa Bendungan}

Berdasarkan pendapat pakar dan observasi lapangan, didapat 11 (sebelas) sub-elemen lembaga yang terkait dalam peningkatan peran desa dalam penyediaan air baku di tingkat desa,yaitu: (A) Balai Suberdaya Alam (SDA), (B) Dinas PU Kabupaten Bogor, (C) Camat Ciawi, (D) Kepala Desa, (E) Aparatur Desa, (F) Masyarakat, (G) Perguruan Tinggi, (H) LSM, (I) Swasta, (J) Lembaga keuangan desa, dan $(\mathrm{K})$ sistem pengelolaan air bersih.

Berdasarkan hasil ploting dalam Digraph memperlihatkan bahwa sebaran setiap sub-elemen menempati empat sektor yaitu sektor seperti terlihat pada Gambar 9A. Dari Gambar 9A terlihat bahwa: sub-elemen Kepala Desa (D), Aparatur Desa (E), Masyarakat (F), dan Lembaga Swadaya Masyarakat $(\mathrm{H})$ terletak pada sektor IV yang merupakan sub sektor elemen kunci yang sangat berpengaruh dalam peningkatan peran desa dalam penyediaan air baku di Desa Bendungan. Subelemen tersebut merupakan kekuatan penggerak (driver power) yang besar dalam penyediaan air baku dengan tingkat ketergantungan (dependence) yang rendah terhadap sub-elemen lembaga yang terkait dengan peningkatan peran desa dalam penyediaan air baku. Apabila keempat sub-elemen tersebut tidak ditangani dengan baik, maka akan menjadi faktor penghambat utama.

Komunitas Ciliwung Hulu (LSM) yang anggotanya terdiri dari berbagai profesi selalu mengedukasi masyarakat tentang pentingnya sungai Ciliwung sebagai sumber penghidupan bukan hanya di bagian hulu saja tetapi juga di bagian hilir, merupakan faktor penggerak untuk konservasi DAS Ciliwung Hulu yang berdampak pada kontinuitas penyediaan air baku di DAS Ciliwung, namun kontribusi LSM tersebut di tingkat desa masih belum terlihat. Disamping itu, peran dan fungsi Kepala Desa dan Aparatur Desa dalam hal penyediaan air baku sebetulnya cukup tinggi, namun saat ini belum begitu terlihat juga, sehingga apabila keempat sub-elemen ini dikaitkan dengan sub-elemen lembaga yang terkait dengan program peningkatan peran desa dalam penyediaan air baku di Desa Bendungan sangat diperlukan.

Sub-elemen lembaga yang terkait lainnya adalah: Balai SDA (A), Dinas PU Kabupaten Bogor (B), Camat (C), dan Lembaga keuangan desa (J). Sub-elemen ini terletak pada sektor III (linkage) yang merupakan sub-elemen yang mempunyai kekuatan pendorong terhadap keberhasilan program peningkatan peran desa dalam penyediaan air baku di tingkat desa, namun memiliki ketergantungan (dependence) dengan sub-elemen lembaga terkait dengan program lainnya yang sangat tinggi.

Setiap tindakan terhadap lembaga lainnya dalam sub-elemen ini akan mempengaruhi suksesnya program peningkatan peran desa dalam penyediaan air baku di tingkat desa, dan sebaliknya apabila sub-elemen ini mendapatkan perhatian yang kurang, maka dapat mempengaruhi 
kegagalan program peningkatan peran desa dalam penyediaan air baku di Desa Bendungan, sehingga yang diperlukan adalah sinergitas antar lembaga tersebut.

Sub-elemen Perguruan Tinggi (G), dan Swasta (I) terletak di sektor II (dependence) yang merupakan sub-elemen akibat dari tindakan perbaikan kelembagaan lainnya. Apabila beberapa subelemen lembaga terkait dengan program peningkatan peran desa dalam penyediaan air baku di tingkat desa ini terpenuhi, maka sub-elemen ini menjadi sangat penting. Peran Perguruan Tinggi dalam kelembagaan adalah memberi masukan terhadap teknologi tepat guna dalam penyediaan air baku, baik dari aspek konstruksi bangunan maupun aspek menjaga kualitas air, sedangkan peran swasta adalah dalam aspek teknis dan finansial.

Sub-elemen terakhir yang melibatkan lembaga terkait dalam peningkatan peran desa dalam penyediaan air baku di tingkat desa adalah sistem pengelolaan air baku (K). Sub-elemen ini terletak pada sektor I (autonomous). Sub-elemen ini mempunyai keterkaitan sangat kecil dan bahkan tidak ada, karena sistem bukan merupakan lembaga tetapi kelembagaan (Dunn, 2003), namun keberhasilan kelembagaan adalah dengan terbentuknya sistem yang baik.

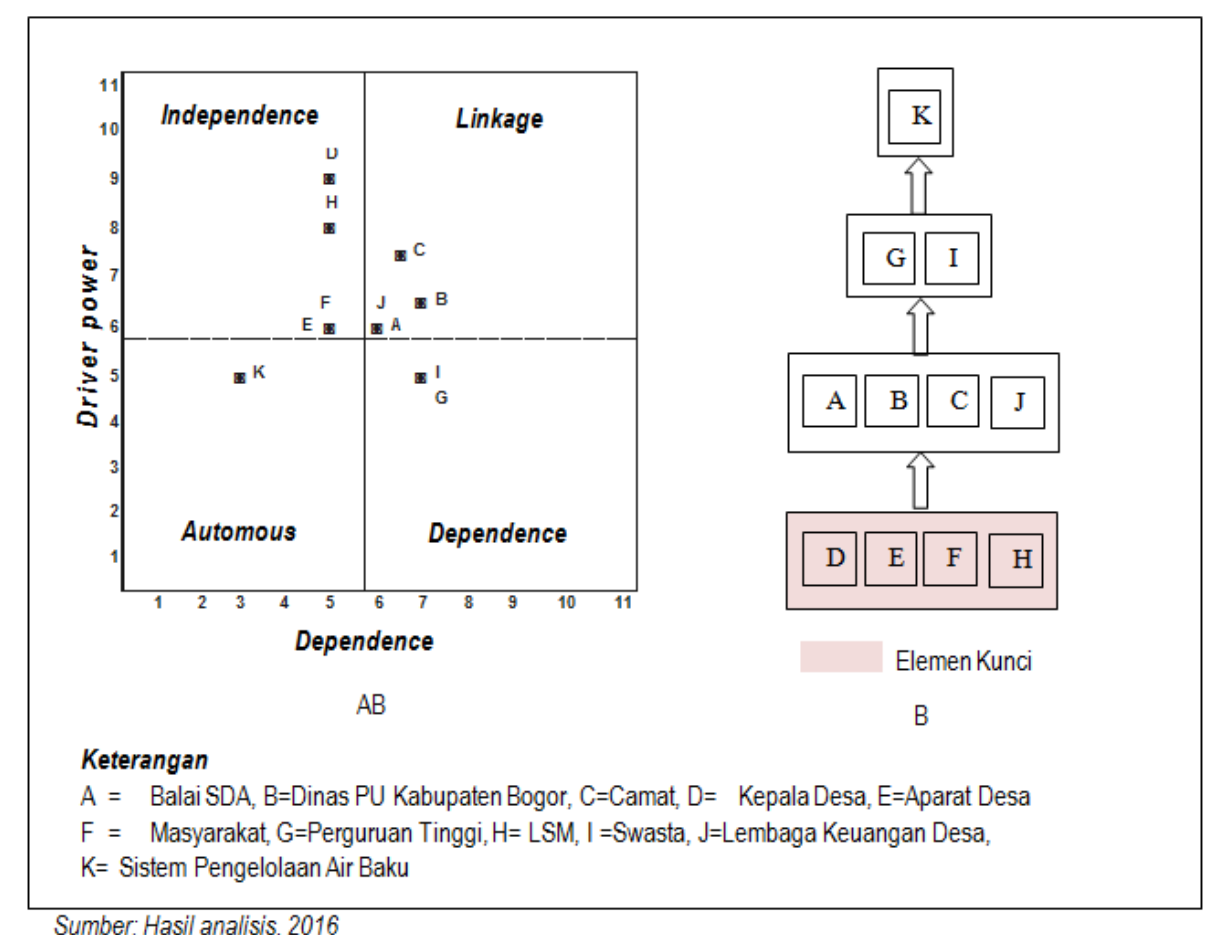

Gambar 9. Matrik Driver Power-Dependence dan struktur hirarki untuk elemen lembaga yang terkait dalam peningkatan peran desa untuk penyediaan air baku di Desa Bendungan

Struktur hirarki hubungan antara sub-elemen lembaga yang terkait dengan program peningkatan peran desa dalam penyediaan air baku di tingkat desa, yaitu Desa Bendungan, Kecamatan Ciawi, Kabupaten Bogor disajikan dalam Gambar 9B, dan terlihat bahwa penanganan lembaga terkait dalam peran desa dalam program penyediaan air bersih di tingkat desa di Desa Bendungan dapat dilakukan melalui empat tahap. Pada tahap pertama yang perlu dilakukan adalah 
mengaktifkan peran LSM, tidak hanya mengedukasi masyarakat tentang konservasi DAS Ciliwung Hulu saja, tetapi pentingnya penyediaan air baku di tingkat desa.Apabila desa sudah menyediaan air baku secara mandiri, maka DAS Ciliwung Hulu akan terjaga, karena kontinuitas pasokan air baku dapat lestari apabila bagian hulunya lestari juga. Kegiatan tersebut dapat berjalan apabila masyarakat dilibatkan, karena masyarakat bukan hanya sebagai obyek saja tetapi juga sebagai subyek. Selain LSM dan masyarakat, peran Kepala Desa dan Aparatur Desa juga sangat penting, karena dapat memotivasi dan memfasilitasi penyediaan air baku walaupun sampai saat ini perannya masih kecil.

Pada level kedua, merupakan faktor penggerak yang meliputi: Balai SDA, Dinas PU Kabupaten, Camat, dan Lembaga Keuangan Desa. Apabila antar institusi tersebut bersinergi membentuk suatu aturan dalam penyediaan air baku, maka akan mendorong lembaga-lembaga lain untuk berkontribusi.Level ke tiga adalah Perguruan Tinggi dan Swasta. Perguruan Tinggi dan Swasta apabila perannya lebih jauh dilibatkan atau ditingkatkan dari yang ada sekarang ini, seperti pada saat perencanaan, maupun pada saat pelaksanaan, maka akan sangat berarti, dan akhirnya lembagalembaga tersebut akan membentuk suatu sistem pengelolaan sumber air agar supaya penyediaan air baku di tingkat desa berkelanjutan.

\section{Peran Antar Kelembagaan Desa dalam Penyediaan Air Baku}

Berdasarkan hasil analisis ISM dari ke empat elemen didapat 13 sub-elemen kunci pengembangan hubungan peran antar kelembagaan penyediaan air bakudengan paradigma kepedulian air, dan disajikan dalam Tabel 1. Dari ke 13 sub-elemen tersebut terdapat empat subelemen yang sama yaitu infrastruktur, sosialisasi, keterlibatan masyarakat, dan aparat desa, sehingga tinggal delapansub-elemen kunci, yaitu: (1) infrastruktur, (2) kerjasama lintas sektoral, (3) sosialisasi, (4) Kepala desa, (5) Aparatur desa, (6) keterlibatan masyarakat, (7) peningkatan kualitas SDM, dan (8) LSM yang dapat dikembangkan.

Tabel 2. Elemen Kunci dari Masing-masing Elemen Peran Antar Kelembagaan pada Penyediaan Air Baku melalui Paradigma Kepedulian Air di Desa Bendungan

\begin{tabular}{lllll}
\hline \multicolumn{1}{c}{ Elemen } & & \multicolumn{3}{c}{ Elemen Kunci } \\
\hline Kebutuhan program & Infrastruktur & $\begin{array}{l}\text { Kerjasama } \\
\text { lintas sektor }\end{array}$ & Sosialisasi & \\
Kendala program & Infrastruktur & Kualitas SDM & Sosialisasi & \\
Tujuan program & Infrastruktur & $\begin{array}{l}\text { Partisipasi } \\
\text { masyarakat }\end{array}$ & Aparat Desa & \\
& Kepala & Aparat Desa & Partisipasi & LSM \\
Lembaga terkait & Desa & & masyarakat & \\
& & &
\end{tabular}

Sumber: Hasil analisis, 2016

Dari delapan sub-elemen kunci tersebut kemudian dibangun struktur kelembagaannya yang berupa pengembangan struktur peran antar kelembagaan dalam penyediaan air dengan paradigma kepedulian air di tingkat desa yang disajikan dalam Gambar 10. Dari Gambar 10, dapat diuraikan bahwa untuk merealisasikan paradigma baru yaitu kepedulian air dalam penyediaan air baku di tingkat desa dalam hal ini adalah Desa Bendungan, maka kendala utama adalah kualitas SDM yang meliputi: aparat desa, masyarakat, dan LSM yang masih rendahharus diatasi terlebih dahulu melalui 
pelatihan, penyuluhan dan pendampingan, agar mereka dapat berpartisipasi dan berperan aktif. Tujuannya adalah agar mereka dapatbekerja secara bersama-sama baik di dalam desa maupun dengan institusi di luar desanya untuk membangun dan mengelola infrastruktur penyediaan air perdesaan. Agar bangunan kerjasama dan partisipasi masyarakat perdesaan dapat berjalan dengan baik, maka harus didahului dengan sosialisasi yang memadai. Peran masing-masing elemen dalam penyediaan air baku di Desa Bendungan disajikan dalam Tabel 2, dimana aparat desa disamping berfungsi sebagai motivator untuk untuk menggerakkan masyarakat juga sebagai figur yang memberi contoh dalam penyediaan air baku.

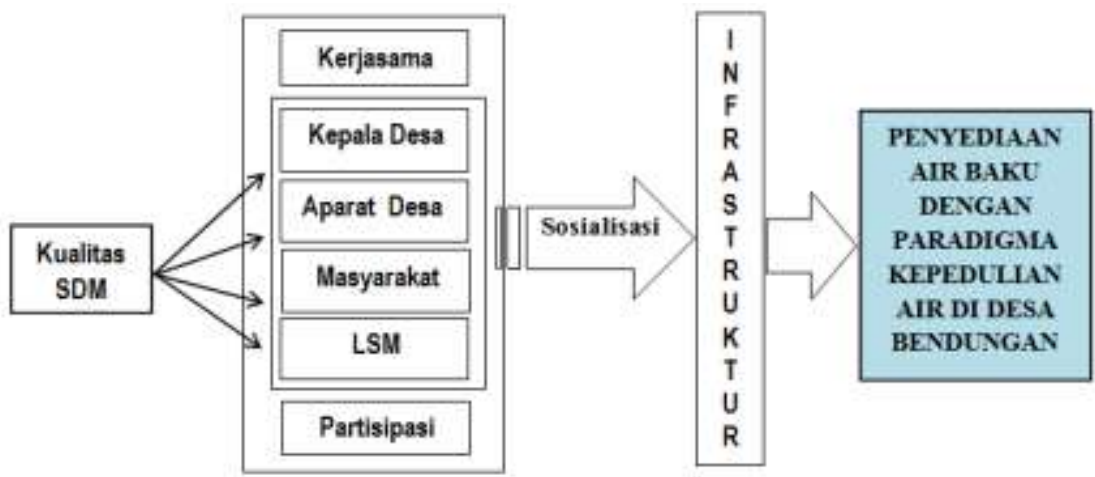

Gambar 10. Pengembangan struktur peran antar kelembagaan dalam penyediaan air baku yang berorientasi pada kepedulian air di tingkat desa

Tabel 3. Fungsi Para Pelaku Utama dalam Penyediaan Air Bakumelalui Paradigma Kepedulian Air di Desa Bendungan.

\begin{tabular}{|c|c|c|c|c|}
\hline \multirow{2}{*}{ Elemen Kunci } & \multicolumn{4}{|c|}{ Pelaku Utama } \\
\hline & Desa & Aparatur & LSM & Masyarakat \\
\hline Infrastruktur & Aset & Pengelola & Pengawas & $\begin{array}{l}\text { Pemanfaat, } \\
\text { pengelola, dan } \\
\text { pengawas }\end{array}$ \\
\hline Kepala Desa & $\begin{array}{l}\text { Kebijakan, } \\
\text { Pengelola }\end{array}$ & $\begin{array}{l}\text { Memberi contoh, } \\
\text { motivator }\end{array}$ & mitra kerja & Motivator, \\
\hline Kualitas SDM & $\begin{array}{l}\text { Peningkatan } \\
\text { peran \& fungsi }\end{array}$ & $\begin{array}{l}\text { Peningkatan } \\
\text { peran \& fungsi }\end{array}$ & $\begin{array}{l}\text { Pelatihan, } \\
\text { pendampingan }\end{array}$ & $\begin{array}{l}\text { Peningkatan peran } \\
\text { dan fungsi }\end{array}$ \\
\hline Sosialisasi & $\begin{array}{l}\text { Penyuluhan dan } \\
\text { pelatihan }\end{array}$ & $\begin{array}{l}\text { Penyuluhan dan } \\
\text { pelatihan }\end{array}$ & $\begin{array}{l}\text { Penyuluhan dan } \\
\text { pelatihan }\end{array}$ & $\begin{array}{l}\text { Penyuluhan dan } \\
\text { pelatihan }\end{array}$ \\
\hline $\begin{array}{l}\text { Kerjasama } \\
\text { lintas sektor }\end{array}$ & Mitra kerja & $\begin{array}{l}\text { Pengarahan dan } \\
\text { pendampingan }\end{array}$ & $\begin{array}{l}\text { Pengarahan, dan } \\
\text { pendampingan }\end{array}$ & $\begin{array}{l}\text { Pengarahan, dar } \\
\text { pendampingan }\end{array}$ \\
\hline
\end{tabular}

\section{SIMPULAN}

Berdasarkan hasil analisa peran antar kelembagaan di Desa Bendungan menggunakan ISM, maka dapat disimpulkan bahwa untuk merealisasikan paradigma baru,yaitu kepedulian air dalam penyediaan air baku kendala utama adalah kualitas SDM yang meliputi: aparat desa, masyarakat, dan LSM yang masih rendah. Kondisi tersebut, harus diatasi terlebih dahulu, dengan tujuanagar masyarakat dapat berpartisipasi dan berperan aktif, serta bisa bekerja secara bersama-sama untuk 
membangun infrastruktur penyediaan air perdesaan. Agar bangunan kerjasama dan partisipasi tersebut dapat berjalan dengan baik, maka harus didahului dengan sosialisasi yang memadai.

Elemen kunci dari keempat elemen yaitu: tujuan program, kendala utama, kebutuhan program, dan lembaga yang terkait dalam hubungannyadengan peran antar kelembagaan pada penyediaan air baku yang berorientasi pada kepedulian air di Desa Bendungan adalah: (a) ketersediaan infrastruktur, (b) kualitas SDM, (c) partisipasi masyarakat, (d) kerjasama, (e) sosialisasi, (f) aparatur desa, (g) Kepala Desa, dan (h) LSM.

Sebagai saran untuk penerapan struktur model hubungan peran antar lembaga dalam kepedulian terhadap penyediaan air baku ditingkat desa adalah dengan: meningkatkan kapasitas desa yang terdiri dari masyarakat dan aparat desa melalui sosialisasi, pelatihan, penyuluhan, dan pendampingan yang dilakukan oleh instansi lintas sektoral.Instansi yang terkait dalam sosialisasi antara lain adalah Pemerintah Daerah Kabupaten Bogor, Dinas PU Kabupaten Bogor, dan LSM, serta Kementerian Desa, Transmigrasi dan Daerah Tertinggal.

\section{REFERENSI}

Badan Perencana Pembangunan Daerah. (2005). Rencana Tata Ruang Wilayah Kabupaten Bogor 2005-2025. Bogor: Bappeda Kabupaten Bogor.

Badan Pusat Statistik (BPS). (2015). Kecamatan Ciawi Dalam Angka. 2014. Bogor: Badan Pusat Statristik Kabupaten Bogor.

Dunn W.N. (2003). Pengantar Analisis Kebijakan Publik. Yogyakarta: Gadjahmada University Press.

Eriyanto \& Sofyar, F. (2007). Riset kebijakan metode penelitian untuk Pasca Sarjana. Bogor:IPB Press.

Marimin. (2004). Teknik dan aplikasi pengambilan keputusan kriteria majemuk. Jakarta:Gramedia Widiasarana Indonesia.

Marpaung, R. (2011). Model pengelolaan air baku air minum berbasis Daerah Aliran Sungai, Studi Kasus DAS Babon Semarang. (Desertasi). Sekolah Pasca Sarjana IPB.

Mirah, D.A. (2014). Penetapan elemen kunci pengembangan agroindustri peternakan dengan Interpretative Structural Modelling (ISM). Zootek Journal, 34 (2), 30-138.

Nuraini,C., Dwidjon,H.D., Masyuri, \& Jamhari. (2016).Model kelembagaan pada agribisnis padi organic Kabupaten Tasikmalaya. Jurnal Agraris, 2 (1), 9-16.

Purwakusuma, W., Baskoro, T.D.P., \& Sinukaban, N. (2011). Mengatasi Krisis Air di Desa, dalam buku Menuju Desa 2030. Yogyakarta:Pohon Cahaya.

Sianipar,M. (2012).Penerapan Intrepretative Structural Modeling (ISM) dalam penentuan elemen pelaku dalam pengembangan kelembagaan sistem bagi hasil petani kopi dan agroindustri kopi. Jurnal Agrointek, 6 (1),8-15.

Susanto, A. (2010). Strategi kebijakan pemanfaatan air tanah sebagai sumber air bersih di Kota Semarang yang berkelanjutan. (Tesis). Sekolah Pasca Sarjana IPB

Thamrin. (2009). Model pengembangan kawasan agropilitan secara berkelanjutan di wilayah perbatasan Kalimantan Barat (Studi Kasus Wilayah Perbatasan Kabupaten BengkayangSarawak). (Desertasi). Sekolah Pasca Sarjana IPB.

Undang-Undang No. 6 tahun 2014 tentang Desa. Lembaran Negara Republik Indonesia Tahun 2014 Nomor 7. 